\title{
VALVASORJEVI PRIKAZI VREMENA IN PODNEBJA V SLAVI VOJVODINE KRANJSKE
}

\author{
dr. Darko Ogrin*, Simona Kosmač, prof. geografije in zgodovine** \\ * Oddelek za geografijo, Filozofska fakulteta Univerze v Ljubljani, \\ Aškerčeva 2, SI- 1000 Ljubljana \\ ** Pudob 52, SI-I 386 Stari trg pri Ložu \\ e-mail: darko.ogrin@ff.uni-lj.si, simona.kosmac@gmail.com
}

\section{Izvirni znanstveni članek}

COBISS 1.01

DOI: $10.4312 /$ dela.40.3.39-53

\section{Izvleček}

O podnebnih in vremenskih razmerah na Slovenskem pred začetkom rednih in neprekinjenih meteoroloških meritev je razmeroma malo znanega. Nekaj več informacij je za 17. st., še posebej za drugo polovico, v kateri je deloval kranjski polihistor J. V. Valvasor. Njegove zapise o vremenu in podnebju lahko dopolnimo tudi z zapisi ljubljanskega kronista J. G. Dolničarja. Kljub določenim omejitvam pri uporabi teh virov lahko $\mathrm{z}$ uporabo dodatnih informacij zadovoljivo predstavimo tedanje vreme in podnebje ter njegove posledice v družbenem okolju.

Ključne besede: podnebje v holocenu, podnebje v predinstrumentalnem obdobju, mala ledena doba, Maunderjev minimum, vremenske ujme, Janez Vajkard Valvasor, Slovenija

\section{PRESENTATION OF WEATHER AND CLIMATE IN VALVASOR'S GLORY OF THE DUTCHY OF CARNIOLA}

\begin{abstract}
Not much is known about the climate and weather conditions on the Slovenian territory before regular and continuous meteorological measurements began to be performed. Some more information exists for the 17 th century, particularly for its second half when J. W. Valvasor was active as a renowned Carniolan polymath. Valvasor's records about weather and climate can be complemented with the records made by the Ljubljana chronicler J. G. Dolničar. Notwithstanding certain reservations, necessary while using these sources, it is possible to present fairly well with the help of this additional information the weather and climate of that time and their impacts on the social environment.
\end{abstract}

Key words: Holocene climate, climate in pre-instrumental period, Little Ice Age, Maunder minimum, weather hazards, Janez Vajkard (Johann Weichard) Valvasor, Slovenia 


\section{UVOD}

Spreminjanje podnebja na Slovenskem do srede 19. st., ko so začele nepretrgoma delovati meteorološke postaje v Ljubljani ter v bližnji okolici v Trstu in Zagrebu, je poleg splošnih trendov, ki veljajo bodisi za Sredozemlje, za Srednjo ali vso Evropo (Ogrin, 2005), slabo poznano. Študij o podnebju Slovenije v predinstrumentalnem obdobju je malo. Malo je znanega tudi o vremenskih in podnebnih razmerah ter odzivih nanje v naravnem in družbenem okolju v posameznih podnebnih obdobjih, npr. v srednjeveškem toplem obdobju ali v mali ledeni dobi. Eno starejših del $\mathrm{s}$ tega področja je domneva o nastanku Triglavskega ledenika v času enega od viškov male ledene dobe (Šifrer, 1963) in Gamsova domneva, da so ob koncu srednjeveškega toplega obdobja, to je v času drugotne, višinske kolonizacije na Slovenskem, nastale v gorskem svetu najvišje kmetije, od katerih so mnoge kasneje opustili (Gams, 1998, str. 117).

Še najbolje poznane so razmere v jugozahodnem delu Slovenije, ki je pod vplivom sredozemskega podnebja. Za ta del je bila izdelana kronika izrednih vremenskih in podnebnih dogodkov za čas od 7. st. do leta 1850 (Ogrin, 1994; 1995) in na tej osnovi opravljena analiza pogostnosti suhih in mokrih let od 14. do 19. st. (Ogrin, 2002), ostrih zim, še posebej tistih, ki so povzročile pozebe oljk (Ogrin, 2007a) in nevihtnih neurij ter njihovih posledic (Ogrin, 2007b).

V novejšem času je nastalo tudi nekaj dendrokronoloških in dendroklimatoloških del, ki so nam lahko v pomoč pri rekonstrukciji zlasti poletnih temperatur in padavin v slovenskem gorskem svetu (Levanič, 2005; 2006; 2007; Levanič, Čufar, 1998) in v jugovzhodni Sloveniji (Čufar in sod., 2008) ter pregledno delo o podnebju na Slovenskem v zadnjem tisočletju (Zwitter, 2012). Omenimo naj še dve diplomski deli študentov oddelkov za geografijo in zgodovino Filozofske fakultete Univerze v Ljubljani. Prvo je bilo tudi uporabljeno kot vir za pripravo tega prispevka in se ukvarja $\mathrm{z}$ vremenom in podnebjem na Kranjskem od 14. do 18. st. s poudarkom na zapisih v Valvasorjevi Slavi vojvodine Kranjske (Levec, 2009), drugo pa z vplivom male ledene dobe na agrarno poselitev na izbranih primerih v Zgornji Savinjski dolini (Zwitter, 2010).

Preučevanje preteklega podnebja je pomembno z več vidikov. Med njimi izpostavljamo krepitev podnebnega spomina, še posebno na tiste vremenske in podnebne dogodke, ki so dosegli raven naravnih nesreč. Ljudje namreč radi potisnemo v pozabo dogodke, ki so za nas neprijetni. Ko se ti po določenem času ponovijo, nas seveda presenetijo in tedaj radi izjavljamo, da je to nekaj izrednega, kar se v preteklosti še ni zgodilo (»česa takega pri nas ne pomnijo niti najstarejši prebivalci«). Že površen pregled preteklega podnebnega in vremenskega dogajanja pa nam hitro razkrije, da temu ni tako in da je naše poznavanje vremenske in podnebne zgodovine pomanjkljivo. Tovrstno znanje je pomembno tudi $z$ vidika vrednotenja trenutnega spreminjanja podnebja in izrednih vremenskih dogodkov, povezanih z njim. Za pravilno oceno človekove vloge pri tem in izdelavo podnebnih projekcij za naslednja desetletja je nujno poznavanje tudi preteklih podnebnih razmer, ko so bili človekovi vplivi na okolje bistveno manjši. Žal se pri tem pogosto srečujemo s pomanjkljivo bazo podatkov o vremenu in podnebju v preteklosti, še posebej za obdobje pred začetkom rednih in sistematičnih meritev. 


\section{METODOLOGIJA}

Namen prispevka je s pomočjo Valvasorjeve Slave vojvodine Kranjske in nekaterih dodatnih virov osvetliti vremensko in podnebno dogajanje na Slovenskem v 17. st. Z vidika podnebne zgodovine uvrščamo to stoletje $\mathrm{v}$ čas druge polovice male ledene dobe, relativno hladnega obdobja, katerega začetek večinoma postavljamo v sredo 15 . st., konec pa $\mathrm{v}$ sredo 19. st. Mala ledena doba je bila regionalna podnebna sprememba na severni polobli, predvsem v Evropi in vzhodnih delih Severne Amerike. Kot morebitna vzroka zanjo se navajata manjša Sončeva aktivnost ter povečanje pogostnosti in intenzivnosti vulkanskih izbruhov. Bila je neenotno hladno obdobje s precejšnjo podnebno variabilnostjo in neenotnim potekom v različnih delih Evrope. Južno od Alp je bila manj izrazita, saj osrednji greben Alp ovira vdore hladnih zračnih gmot s severa. V primerjavi s sredino 20. st. so bile povprečne letne temperature v Evropi nižje za 1 do $1,5^{\circ} \mathrm{C}$, zime so bile zelo hladne in suhe (januarske temperature so bile nižje za 2 do $4{ }^{\circ} \mathrm{C}$ ), do $10 \%$ manjša je bila tudi količina padavin. Imela je tri viške ohladitve: prvega v drugi polovici 16. st., drugega (Maunderjev minimum) med 1645 in 1715 in tretjega od sredine 30. do sredine 70. let 18. st. Zaradi dolgih in ostrih zim so bile pogoste težave v kmetijstvu, alpski ledeniki so se spustili najnižje po zadnji poledenitvi, zmrzovale so reke in morje v Rokavskem zalivu in ob obali Nizozemske ter voda v beneških lagunah (The climate of Europe, 1984; Shindell, 2009, str. 520-522, 550-551).

Paleoklimatske rekonstrukcije zadnjih 500 let predinstrumentalnega obdobja, ki se v Evropi večinoma konča z 18. oziroma 19. st., temeljijo na analizi zgodovinskih virov, ki direktno ali indirektno govorijo o preteklem vremenu in podnebju. Značilnost teh zapisov je, da imajo praviloma nizko ločljivost in so posejani na redko, tako da ne omogočajo popolnih podnebnih rekonstrukcij. Med direktne vire sodijo denimo razni opisi podnebja in vremena $\mathrm{v}$ horografijah ter zapisi o izrednih vremenskih dogodkih v raznih kronikah, $\mathrm{s}$ pomočjo katerih lahko ugotavljamo frekvenco posameznih dogodkov v določenem času (npr. pozeb, suš, nevihtnih neurij ipd.). Z uporabo indirektnih virov sklepamo o preteklem vremenu in podnebju s pomočjo njegovih posledic (fenološki podatki, podatki o letinah, gibanju cen živil). Uporabni so tudi podatki o gibanju ledenikov, tako iz zgodovinskih virov kakor rekonstrukcije nekdanjega stanja, ki jih dobimo z analizo morenskega gradiva in raziskavo lišajev. Ena pomembnejših metod je dendroklimatološka metoda, pri kateri sklepamo na podnebne razmere iz serij drevesnih branik.

Težave pri uporabi zgodovinskih virov za rekonstrukcijo preteklega podnebja so, da v splošnem dlje nazaj gremo, manj jih je, manj so zanesljivi in težja je njihova verifikacija. 17. st. je eno od obdobij, ko imamo za ozemlje današnje Slovenije dovolj zgodovinskih virov, ki nam omogočajo vsaj osnovni vpogled v vremensko in podnebno dogajanje v tistem času. Konec 17. st. je izšlo delo J. V. Valvasorja (1641-1693) z naslovom Slava vojvodine Kranjske (Valvasor, 1689; delni prevod v slovenščino: Valvasor, 1984; slovenski prevod celotnega prvega, drugega, tretjega in četrtega zvezka: Valvasor, 2009-2012). Avtor je v skladu s tradicijo podobnih del tedanjega časa vsestransko opisal Kranjsko, historično deželo, ki je obsegala precejšen, predvsem osrednji del današnje Slovenije (slika 1). V začetku tretje knjige opisuje splošne podnebne značilnosti Kranjske, v nadaljevanju 
pa se podrobneje posveti izrednim vremenskim dogodkom, predvsem tistim, ki so imeli negativen vpliv na kmetijske pridelke.

Valvasorjev opis izrednih vremenskih dogodkov smo uporabili za izdelavo kronologije teh dogodkov v 17. st. in v začetku 18. st., to je do konca Maunderjevega minimuma. Eden temeljnih virov za kronologijo so bili tudi vremenski podatki ljubljanskega kronista J. G. Dolničarja (1655-1719) za obdobje 1660-1718 (Pučnik, 1980, str. 56-59). Za izpopolnitev kronike smo uporabili tudi ustrezne podatke iz kronike izrednih vremenskih in podnebnih dogodkov za obsredozemski del Slovenije (Ogrin, 1994; 1995), iz cerkvene kronike fare Rečica ob Savinji (Novak, 1999, str. 111-112), iz kronike letin in naravnih nesreč Središča ob Dravi na Štajerskem (Kovačič, 1910; ponatis1986) in iz zgodovine slabih letin, lakot in draginj na Dravskem polju (Slekovec, 1885, str. 120-123). Zavedamo se, da kronika ni popolna in da obstajajo tudi primarni viri, s katerimi bi jo mogli še izpopolniti. Kljub temu pa izdelana kronika omogoča vpogled v značilnosti pojavljanja izrednih vremenskih dogodkov tedanjega časa in njihovih posledic.

\section{Slika 1: Meje današnje Slovenije, Kranjske v 17. st. in podnebna členitev Slovenije}

Figure 1: Borders of present-day Slovenia and of Carniola in the 17th century and climate division of Slovenia

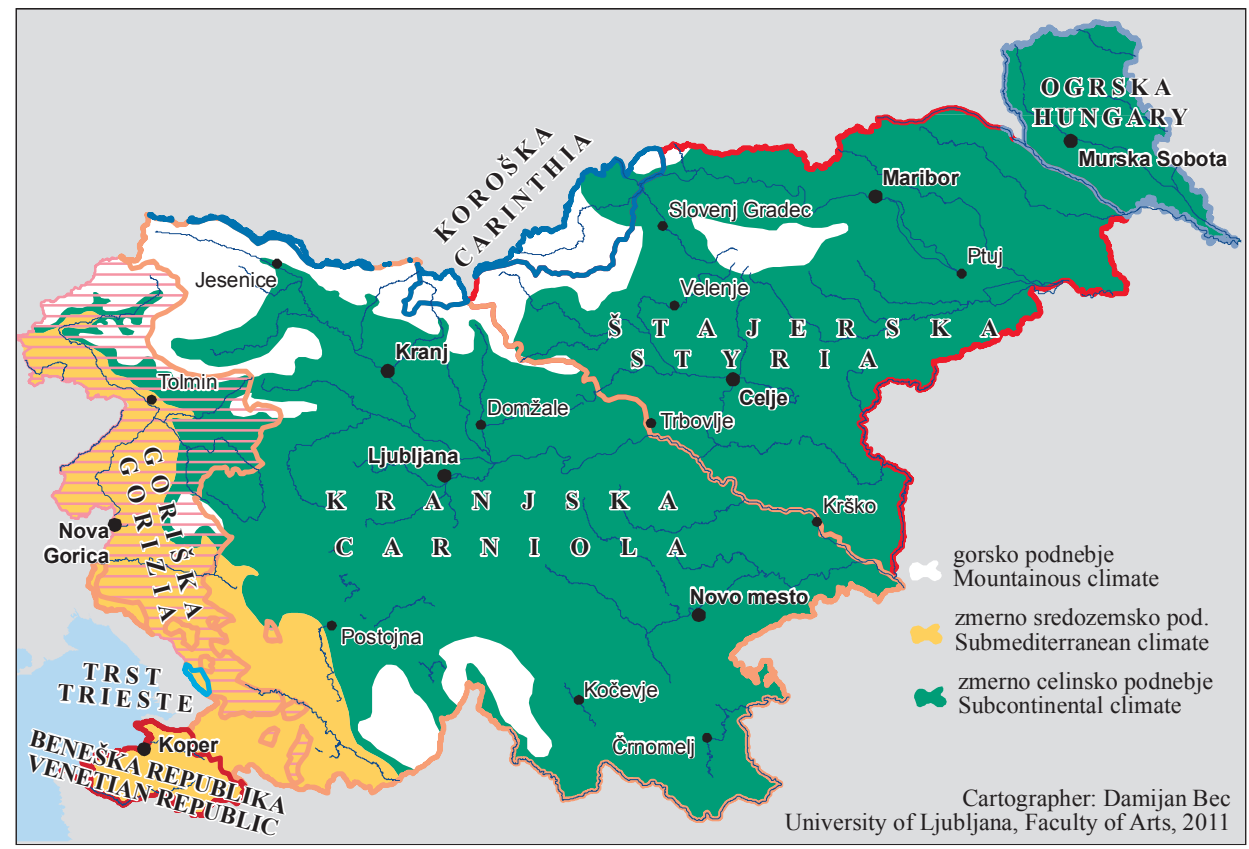




\section{VALVASORJEVE OPREDELITVE VREMENA IN PODNEBJA KRANJSKEV I7. STOLETJU}

\section{I. Splošne oznake podnebja in značilnosti letnih časov}

Sodobne podnebne delitve Slovenije (Ogrin, 1996; Ogrin, Plut, 2009, str. 88-91) poudarjajo stikanje in prepletanje treh tipov podnebja na njenem ozemlju: gorskega, zmerno sredozemskega in zmerno celinskega (slika 1). Za vse tri je značilna netipičnost, če jih primerjamo s pravim gorskim, sredozemskim ali celinskim podnebjem, ter prepletanje njihovih glavnih značilnosti, zato jim pogosto dodajamo predpono 'sub' (submediteransko, subkontinentalno), ali jih označujemo za 'zmerno' oziroma 'omiljeno' (sredozemsko, gorsko, celinsko). Pri značilnostih podnebnih elementov poudarjamo njihovo veliko prostorsko in časovno spremenljivost. Glede na to, da je Kranjska v Valvasorjevem času obsegala tako del alpskega sveta, praktično vso osrednjo in jugovzhodno Slovenijo, kjer prevladujejo zmerno celinske podnebne poteze, ter del obsredozemskih pokrajin na jugozahodu današnje Slovenije, ne preseneča, da je Valvasor ob opisu splošnih podnebnih razmer Kranjske izpostavil tako pestrost podnebja kakor tudi njegovo spremenljivost. »Akoravno Kranjska ni posebno velika, občutimo v podnebju tako velike razlike kakor nikjer drugod. Zrak je sicer še precej mil, vendar pa tudi dokaj spremenljiv: spreminja se rad ne le s časom, ampak tudi s krajem in pokrajino; zato zorijo sadeži, zlasti drevesni, mnogo prej v tem kakor onem kraju, ..., čeprav razdalja med takimi kraji često ne znaša več ko dan hoda ali dva." (Valvasor, 1689, knjiga III, str. 306; slovenski prevod: Valvasor, 2009).

Pri opisu značilnosti letnih časov pri zimi poroča, da zime v času nastajanja njegovega dela, to je v drugi polovici 17. st., niso bile ostre. »Zima pa ni tako huda, je precej mila in znosna. Sicer večkrat sneži, toda sneg ne obleži dolgo, temveč kmalu izgine ... «(Valvasor, 1689, knjiga III, str. 307; slovenski prevod: Valvasor, 2009). Omenja pa velike razlike med posameznimi deli tedanje Kranjske: »Vendar je tudi glede mraza znatna razlika na Kranjskem, zakaj na Gorenjskem je včasih še vse trdo od mraza in je sneg še prav visok, ko se na Dolenjskem že vse taja in poganja, a v Istri in tam okoli že vse cvete. "(Valvasor, 1689, knjiga III, str. 307; slovenski prevod: Valvasor, 2009).

Opredelitev zim kot milih in znosnih je, gledano $\mathrm{z}$ današnje perspektive, $\mathrm{v}$ neskladju s splošnimi značilnostmi male ledene dobe, kamor sodi tudi druga polovica 17. st., in dejstvom, da je bil med leti 1645 in 1715 t. i. Maunderjev minimum, ko so se vrstila hladna leta z mrzlimi in dolgimi zimami. Da se zime v 17. st. Valvasorju niso zdele pretirano hude, je morda posledica tedanjega prevladujočega dojemanja ostrejših zim za normalne, saj so od okoli leta 1655 do približno 1710 v Srednji Evropi prevladovale mrzle zime (Pfister, 1995). Kljub različnemu regionalnemu poteku male ledene dobe ni dokazov, da bi bile zime na Slovenskem v drugi polovici 17. st. toplejše kot v sosednjih deželah. Ravno nasprotno - iz različnih kronoloških zapisov (preglednica 1) je razvidno, da je bilo od leta 1645 do izida Slave vojvodine Kranjske vsaj pet hudih zim s pozebami $(1648,1653 / 54,1660,1683 / 84$ in 1684/85). Tem je takoj na začetku 18 . st. sledila serija 
še vsaj petih hudih zim $(1708 / 09,1710 / 11,1712 / 13,1714 / 15$ in 1715/16), od katerih se kot najhujšo, celo kot eno hujših v zadnjih 500 letih v večjem delu Evrope omenja zimo 1708/09 (Xoplaki, Maheras, Luterbacher, 2001, str. 598). Malo verjetno je tudi, da bi Valvasorjeva opredelitev zim nastala pod vplivom razmer v prvi polovici 17. st., to je pred njegovim rojstvom, ko so bile po Pfistru (1995) zime v Srednji Evropi med leti 1615 in 1655 nekoliko toplejše.

$\mathrm{V}$ prid neugodnim razmeram $\mathrm{v}$ hladni polovici leta govorijo tudi slabe žitne letine na Kranjskem v času Maunderjevega minimuma leta 1675, 1677, 1685, 1695, 1696, 1708 in 1709 (Šorn, 1950, str. 172; Valenčič, 1977, str. 20-22, 122-24). Za dober pridelek ozimnih žit je namreč potrebna dovolj vlažna jesen, ne preveč ostra in dolga zima, dovolj padavin spomladi in ne preveč mokro vreme v času zorenja in žetve. Pri jarih žitih dolga zima vpliva na zakasnitev setve, kar lahko povzroči v višjih legah pozno dozorevanje ali pa žito zaradi hitrega nastopa mraza sploh ne dozori. Zato je za te lege ugodno, da je v začetku jeseni suho in toplo vreme.

Slabe vremenske razmere in z njimi povezane skromne letine konec 17. in v začetku 18. st., živinska kuga in iz leta v leto naraščajoči davki so bili po mnenju Šorna (1950) tudi glavni vzrok za kmečke upore na Slovenskem v začetku 18. st. V tem času se je zaradi več zaporednih slabih letin gospodarski položaj mnogih kmetov zelo poslabšal, zato so številni zapustili svoja prebivališča ter se odselili na tuje (Šorn, 1950). Zwitter (2010; 2012) tudi ugotavlja, da je zaznati sicer ne obsežen, še manj pa trajen vpliv zgodnjenovoveške male ledene dobe na agrarno poselitev visoko ležečih kmetij na Solčavskem v vzhodnem delu slovenskih Alp. V času vrhunca Maunderjevega minimuma so bile podnebne razmere za ustaljene kmetijske prakse marsikje tako neugodne, da so nekatere kmetije opustili.

Iz podnebnih rekonstrukcij za Srednjo Evropo vemo, da so bile pomladi v 17. st. in v prvi polovici 18. st. v glavnem hladne, poletja precej spremenljiva, s hladnejšimi v začetku in ob koncu stoletja ter z zelo hladnimi v prvi polovici 18. st. Sredi stoletja so se vrstila nadpovprečno topla poletja (Glaser, 2001, str. 94). Pfister (1995, str. 92-117) omenja hladne pomladi zlasti v 90. letih 17. in 40. letih 18. st. V naši kroniki se kot vroči (in sušni) omenjata le poletji 1616 in 1644, kot suho (vsaj v Primorju) tudi poletje 1660. Na slabe rastne razmere konec 17. in v začetku 18. st., to je na podpovprečne temperature od maja do avgusta (in kratko vegetacijsko dobo), morda kaže tudi macesnova kronologija za zgornjo gozdno mejo v jugovzhodnih Alpah (Levanič, 2005; 2007). Pri opisu poletnih podnebnih razmer je bil Valvasor očitno pod vplivom sredine stoletja, saj pravi: »Poleti občuti Kranjska prijetno umirjeno toploto. " (Valvasor, 1689, knjiga III, str. 310; slovenski prevod: Valvasor, 2009). Ponovno pa poudarja velike razlike med alpskim delom Kranjske in nižje ležečimi predeli na jugovzhodu in v bližini morja: „Gorenjska ima zgodaj zjutraj skoraj nekoliko hladen zrak, ker leži visoko in so takoj nad njo snežniki. Proti Hrvaški pa je zelo toplo in vroče. Na Krasu in v Istri sonce močno žge in silno greje. Drugače pa dež in pogosta toča precej slabita in blažita pripeko; tudi snežniki store svoje, ker z njih vedno pihlja svež in hladen zrak ali veter, ki zmanjšuje vročino. «(Valvasor, 1689, knjiga III, str. 307; slovenski prevod: Valvasor, 2009). 


\subsection{Nevihtna neurja}

Iz pozornosti, ki jo Valvasor namenja nevihtam in spremljajočim pojavom, še posebej toči, lahko domnevamo, da je bila glavna značilnost tople polovice leta v njegovem času velika pogostnost neviht in velika škoda, ki so jo povzročale. Omenja, da na Kranjskem redkokdaj mine dan brez bliskanja in grmenja in da je več neviht v Primorju in v gorah ter da je na sosednjem Koroškem in Štajerskem prav tako veliko toče, vendar manj kot na Kranjskem. Razlaga, da ta ujma zajame različno široke pasove (od enega streljaja do ene milje), ki so dolgi tudi več kot sedem milj, kar bi pomenilo nad $50 \mathrm{~km}$ (Vilfan, 1954), nikoli pa ne pustoši po celi deželi. Dogaja se, da isti pas opustoši dve ali tri leti zaporedoma, prav tako zadane večkrat na leto ista območja. Včasih padajo iz oblakov kot lešnik debela zrna, včasih debela kot pest, »... včasih pade toča za tri ali štiri prste na debelo in obleži do naslednjega dne. "(Valvasor, 1689, knjiga III, str. 311; slovenski prevod: Valvasor, 2009).

Valvasor poroča, da nevihte povzročajo Kranjski veliko škodo. Toča ne uniči samo posevkov, ampak tudi drevesa in živino: »Kdajpakdaj toča pada tako hudo, silno in $s$ tako močnim vetrom, da celo najmočnejša drevesa takorekoč vsa zvita obležijo od vetra, ki piha $v$ tako močnih sunkih in tako okrutno. Kranjska bi bržčas bila pravo jedro srečnih in rodovitnih dežel, kolikor ji ta toča ne bi njene sreče občutno zmanjševala: če izračunamo škodo, ki jo povzroča, je ta tako velika, da je običajno vsako leto uničena petina sadnih in drugih rastlin in s tem deželi izpade in se izgubi gotovo še precej več." (Valvasor, 1689, knjiga III, str. 311; slovenski prevod: Valvasor, 2009). Ugotavlja pa, da zaradi tega ni podražitev kmetijskih pridelkov, saj nevihte s točo običajno prizadenejo le manjša območja. Izpostavlja pa tragično usodo revnega človeka, saj mu toča uniči še tisto malo, kar ima, še posebej, če ga ta ujma prizadene dve ali več let zaporedoma: "Ko nevihta popolnoma zbije k tlom ozimno žito, kot je pšenica, rž in podobno, in zatem zatolče $v$ tla jaro žito, ajdo, proso, fižol, grah in lečo, in drugo, potem pride ubogi kmečki človek $v$ hudo stisko in bedno stanje. ... Kogar udari, ta to dobro občuti, posebno priden kmet, ki ga to potisne $v$ tako stisko in revščino, da mora trpeti pomanjkanje kruha in da mora s svojci trpeti revščino. Z upanjem zre v prihodnje leto. Če te revne vaščane ... ponovno tako močno in uničujoče prizadene, ... potem morajo mleti skorjo od dreves in kruh delati iz tega... « (Valvasor, 1689, knjiga III, str. 311; slovenski prevod: Valvasor, 2009). Poleg velike škode, ki jo povzroča toča, omenja tudi človeške žrtve (še posebej pri košnji), pobite živali (ovce) in poškodbe na objektih (Valvasor, 1689, knjiga III, str. 321; slovenski prevod: Valvasor, 2009).

Če je zaupati Valvasorjevim poročilom o nevihtnih neurjih in podatkom iz kronik, potem lahko sklepamo, da je bila pogostnost le-teh v 17. st. (podobno tudi v 18. st.) na podobni ravni kot v današnjem času, ko večjo pojavnost teh vremenskih ekstremov večinoma povezujemo s splošnim ogrevanjem ozračja. Primerjava podatkov iz vremenske kronike za 17. st. (preglednica 1) in kronike za 20. st., ki jo je sestavil Trontelj (1997) in je bila za zadnja tri leta 20. st. dopolnjena s podatki v reviji Ujma (Šipec, 1999; 2001a; 2001b), pokaže, da je bilo v drugi polovici 17. st. v Ljubljani in okolici osem večjih nevihtnih neurij, v drugi polovici 20. st. pa devet. Zanimivo je, da sta si sloga zapisovanja 
škode in posledic teh ujm v današnjem času in pred 200 do 300 leti zelo podobna. Iz zapisov je tudi razvidno, da se značilnosti neurij in vrsta povzročene škode do današnjih časov nista bistveno spremenili, le gola eksistenca ljudi danes ni več tako ogrožena, kot je bila nekoč.

Preglednica 1: Klasifikacija vremenskih ujm v 17. st. in za časa Maunderjevega minimuma na Slovenskem na osnovi kronoloških zapisov

Table 1: Classification of weather hazards in the Slovenian lands in the 17th century and during the Maunder minimum based on chronical records

\begin{tabular}{|c|c|}
\hline $\begin{array}{l}\text { Ostre zime (Harsh winters): 1608/09, 1634/35, } \\
1648,1653 / 54,1660,1683 / 84,1684 / 85,1708 / 09 \text {, } \\
1710 / 11,1712 / 13,1714 / 15,1715 / 16\end{array}$ & $\begin{array}{l}\text { Mile zime (Mild winters): } 1627 / 28,1681 / 82 \text {, } \\
1702,1704 / 05,1707 / 08,1709 / 10\end{array}$ \\
\hline $\begin{array}{l}\text { Vroča in suha poletja (Hot and dry summers): } \\
1616,1644,1660,1701,1704,1705,1708\end{array}$ & $\begin{array}{l}\text { Deževna leta (Rainy years): 1627, 1631, 1654, } \\
1703,1706,1707,1710,1711,1713,1714,1715\end{array}$ \\
\hline $\begin{array}{l}\text { Nevihtna neurja (toča, močan veter) (Severe } \\
\text { storms with hail, strong winds): 1613, 1622, } \\
1628,1636,1637,1644,1650,1654,1657,1665, \\
1672,1677,1683,1685,1686,1688,1691,1693, \\
1698,1700,1701,1708,1710\end{array}$ & Napadi kobilic (Locust invasions): 1611, 1644 \\
\hline $\begin{array}{l}\text { Poplave (Floods): 1628, 1631, 1633, 1635, 1688, } \\
\text { 1702, 1703, 1707, 1710, } 1714\end{array}$ & $\begin{array}{l}\text { Lakote, draginje (Famines, high costs of living): } \\
1612,1628,1629,1654,1675,1685,1686,1705,1711\end{array}$ \\
\hline
\end{tabular}

Viri/Sources: Valvasor, 1689; Pučnik, 1980, str. 56-59; Ogrin, 1994; 1995; Levec, 2009; Novak, 1999, str. 111-112; Kovačič, 1910; Slekovec, 1885, str. 122

\subsection{Ostale vremenske in podnebne značilnosti}

Ostalim vremenskim in podnebnim značilnostim Kranjske namenja Valvasor manj pozornosti. Tako kakor danes poudarjamo, je tudi on mnenja, da je Kranjska dobro namočena: "Po dežju Kranjske ne žeja, ker jo ta pogosto blago napoji, tudi kadar se ga najmanj nadeja.« (Valvasor, 1689, knjiga III, str. 309; slovenski prevod: Valvasor, 2009). Omenja občasna sušna obdobja, ko ni padavin tudi do 14 dni in močne, kratkotrajne nalive poleti in tudi jeseni, ki povzročijo visok vodostaj rek. Pri opisu podnebnih značilnosti poplav posebej ne omenja, iz zapisov v kronikah pa je moč razbrati, da jih je bilo v 17. st. v osrednji Sloveniji vsaj pet $(1628,1631,1633,1635,1688)$.

Pri snegu poudarja njegovo nezanesljivost in dejstvo, da snežna odeja običajno ni visoka in da se dolgo ne obdrži. Za primorski del pravi, da sneži bolj poredko in da se sneg obdrži le kratek čas. Kot najbolj megleni del Kranjske poudarja spodnji del Ljubljanske kotline z Ljubljano. Po njegovem mnenju je ta megla nezdrava, ker povzroča kašelj in katar, citira pa nekega zdravnika, ki trdi nasprotno: "... da pogosta in gosta megla Ljubljančanom malo škoduje zaradi mnogega ognja in dima, ki se z njim zrak čisti...". Po Valvasorjevem mišljenju "... gosta megla ne zastrupi tako kmalu zraka in ga ne dela sprejemljivega za strupene in nalezljive bolezni, ker jo pogost dim izboljšuje. "(Valvasor, 
1689, knjiga III, str. 309; slovenski prevod: Valvasor, 2009). Danes bi seveda težko soglašali s tem mnenjem. Malo megle imajo na Gorenjskem, kjer pa je pogostejša slana: "Zgodaj zjutraj, ko pade slana, je vse belo kakor pobeljen zid. Dostikrat se drži slana tri dni zapovrstjo; to napravi ajdi na polju nepopisno škodo, tako da se precej nato žito podraži. Prebivalci sprejmejo bledega gosta z majanjem glave in zaskrbljenim pogledom ter vidijo v njem belo žalno tančico polja. « (Valvasor, 1689, knjiga III, str. 309; slovenski prevod: Rupel, 1969).

Slika 2: Megla nad zahodnim delom Posavskega hribovja (foto: D. Ogrin)

Figure 2: Fog above the western part of the Sava Hills (photo: D. Ogrin)

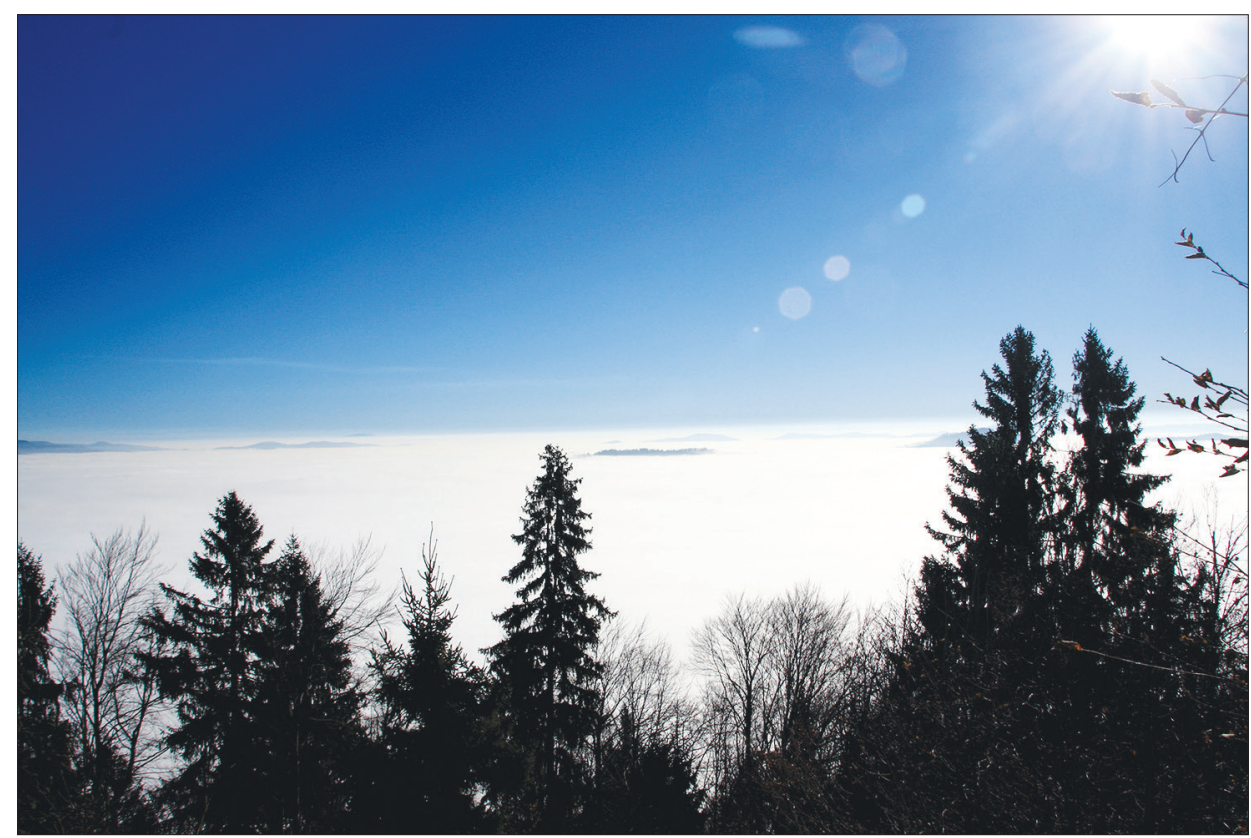

Glede na Valvasorjeve zapise in današnje stanje pri vetrovnosti ni bistvenih sprememb. Tudi Valvasor ugotavlja, da Kranjska ni preveč izpostavljena vetrovom, da ti niso stalni, ampak zelo spremenljivi. Za notranjost Kranjske omenja, da lahko močnejši, hladni vetrovi pihajo od vzhoda in da poleti nastajajo viharni vetrovi ob nevihtah. Kot najbolj vetrovne pokrajine izpostavlja Kras, Pivko in Istro, kjer pihajo tako mrzli vetrovi, »... da v srce režejo. ... Na Krasu in Pivki veter tako močno piha zlasti pozimi, ko vzhodnik žvižga in drvi s tako močjo, da niti ljudje niti živina ne morejo napredovati, kadar udari z vso silo in ravno s polnimi lici izpiha svojo jezo. Takšen je dva, tri, štiri ali pet dni, in še več dni zaporedoma. S svojo silovitostjo vrže na tla človeka in konja; zato mora tisti, ki naj ga ne vrže po tleh ali odtrga z mesta, kadar je veter prav nebrzdan, ostati doma. Ne odnaša le listja, ampak tudi pesek in kamne; žvižga tako močno, da bolijo ušesa. Pravijo mu burja in prihaja nekako iz vzhoda. Če se resno loti, ...ne more noben človek obstati, tedaj je 
nemogoče, da bi kdo peš ali na konju prišel preko Gabrka iz Senožeč v Trst ali iz Trsta v Senožeče... «(Valvasor, 1689, knjiga III, str. 308; Valvasor, 1689, knjiga IV; slovenski prevod: Valvasor, 1984; 2009).

Slika 3: Valvasorjeva upodobitev burje na Gabrku, ki prevrača konja in moža (Valvasor, 1984, str. 49)

Figure 3: Valvasor's depiction of bora on Gabrk ridge as it knocks down a horse and a man (Valvasor, 1984, p. 49)

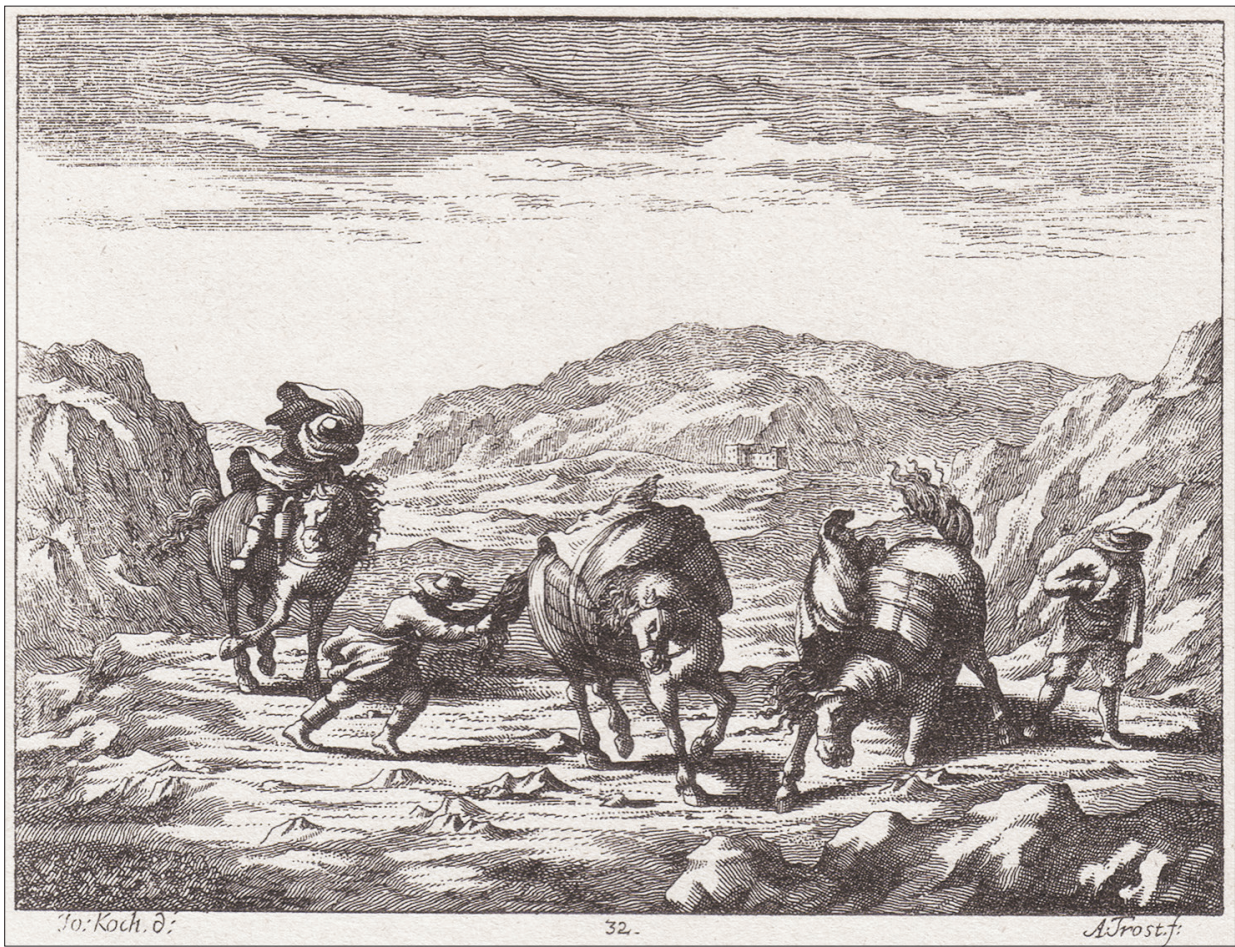

Z vremenom in podnebjem je povezana še ena nadloga, ki je tepla tedanje prebivalstvo in je v današnjem času pri nas ne poznamo, to so napadi kobilic selivk (Locusta migratoria). Čeprav na splošno 17. st. zaradi male ledene dobe ni bilo najbolj ugodno za kobilice, so le-te napadle Kranjsko vsaj dvakrat, leta 1611 in 1644 . Zadnji napadi kobilic na današnje ozemlje Slovenije so bili zabeleženi v 18. st., zanesljivo leta 1720 (Ogrin, 1995, str. 295) in leta 1782 (Slekovec, 1885, str. 123). Za invazijo leta 1611 je Valvasor zapisal: "Nenavadno vinorodno leto. Pa zopet nesreča. Celi oblaki kobilic so prihajali od hrvaške meje. Ko so odšle, je vse izgledalo kakor požgano in pokošeno." (Valvasor, 1689, knjiga XV, str. 551; slovenski prevod: Levec, 2009). Za napad kobilic leta 1644 izvemo, da je bil povezan z vročim in suhim vremenom v začetku poletja (Ogrin, 1995, str. 290). 
Kobilice, ki so prihajale na ozemlje današnje Slovenije, so izvirale iz Male Azije. Tu so se ob ustreznem vremenu zelo namnožile in prešle iz individualne v skupinsko fazo življenja. Pri iskanju hrane so se ob sušnem in dovolj toplem vremenu razširile ob Donavi v Panonsko kotlino, od koder so se selile v različne dele Evrope, tudi čez dinarske prelaze na današnjem slovenskem ozemlju v Italijo. Običajno so prišle poleti, najpogosteje avgusta. Ker same nimajo velikih sposobnosti letenja, je za njihovo širitev zelo pomemben tudi ustrezen veter (Camuffo, Enzi, 1991). Ker v današnjem času v naših geografskih širinah vzhodni vetrovi poleti niso najbolj pogosti in ne pihajo dlje časa, lahko postavimo tezo, da je bila v preteklosti, vsaj v času invazij kobilic, vetrovna shema nekoliko drugačna od današnje. Postavlja se vprašanje, ali se bodo morda zaradi napovedane otoplitve podnebja, podaljšanja tople polovice leta in večje verjetnosti daljših sušnih obdobij v 21. st., ponovno vzpostavili ugodnejši pogoji za invazije kobilic v naše kraje.

Slika 4: Leta 1442, 1474, 1611, 1644, 1720 in 1741 so se s pomočjo vetra ob suhem in dovolj toplem vremenu iz Panonske kotline na ozemlje današnje Slovenije razširile kobilice selivke (Locusta migratoria) in za seboj pustile pravo opustošenje. Na sliki je upodobitev invazije kobilic iz Valvasorjeve Slave vojvodine Kranjske (Valvasor, 1984, str. 307).

Figure 4: In the dry and rather warm weather in the years 1442, 1474, 1611, 1644, 1720 and 1741, propelled also by the wind, migratory locusts (Locusta migratoria) spread from the Pannonian lowlands over the territory of the present-day Slovenia, and caused complete devastation. The picture, taken from Valvasor's Glory of the Dutchy of Carniola, shows the invasion of locusts (Valvasor, 1984, p. 307).

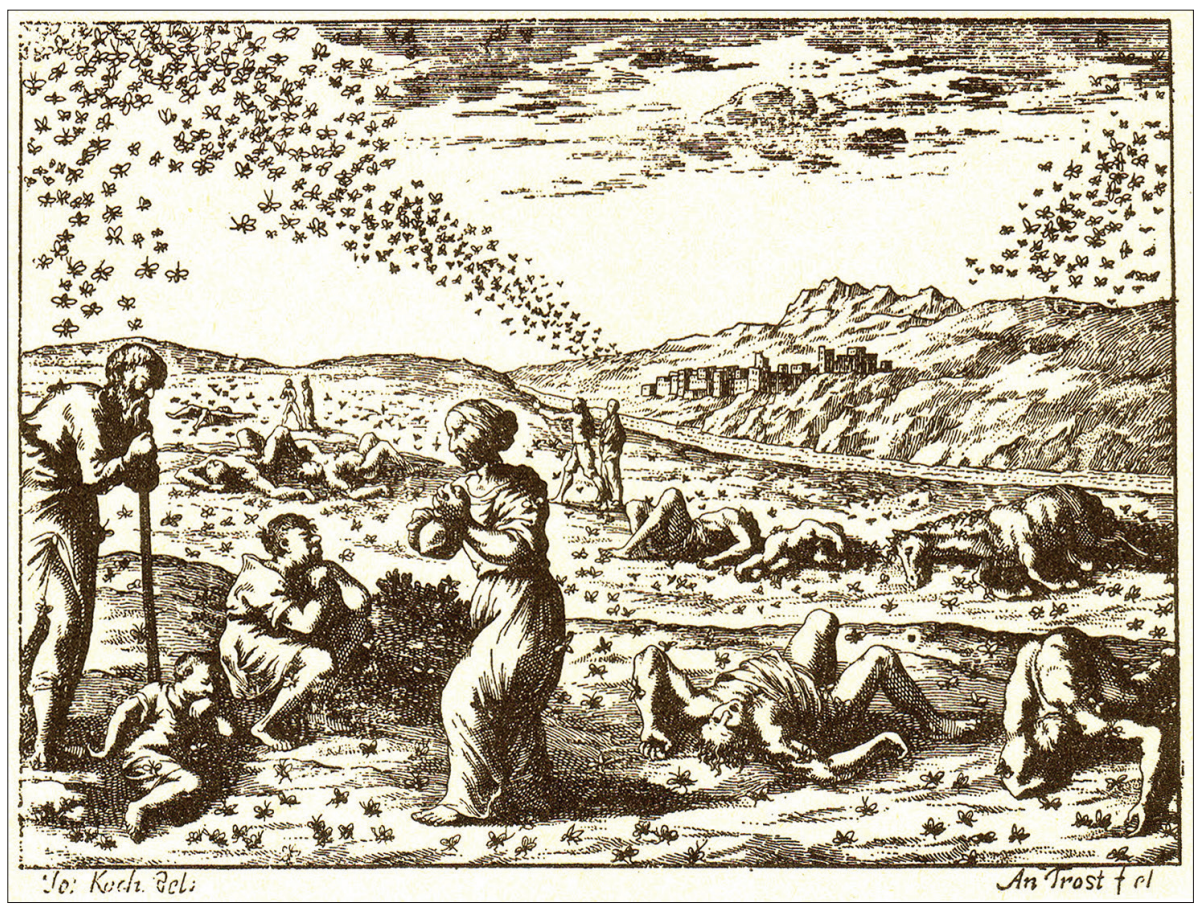




\section{SKLEP}

Za 17. st. imamo dva pomembnejša vira, ki nam prinašata veliko informacij o takratnem vremenu in podnebju na Slovenskem, Valvasorjevo Slavo vojvodine Kranjske in Dolničarjevo Ljubljansko kroniko. Valvasorjevi opisi vremena in podnebja ne temeljijo na strokovnih meritvah in opazovanjih, temveč le na občasnih vizualnih opazovanjih avtorja in njegovih informatorjev. Določene razlage (in opisi) so z vidika sodobne znanosti neustrezne, zato smo v prispevku upoštevali le tiste, ki so se nam zdele sprejemljive. Oba temeljna vira o vseh dogodkih nista soglasna. Valvasorju lahko pripišemo tudi določeno stopnjo nezanesljivosti, kar zahteva dodatno previdnost pri uporabi vira. Čeprav sta bila sodobnika, sta tudi redko opisovala iste dogodke. To nas napeljuje na sklep, da je bilo morda dogodkov več, kakor sta jih lahko s pomočjo informacijskih virov tedanjega časa zaznala oba kronista. Kljub vsem zadržkom smo mnenja, da si lahko s sintezo vseh podatkov, izločitvijo nestrokovnih razlag, primerjavo s podnebnimi rekonstrukcijami, narejenimi s pomočjo drugih metod, in rekonstrukcijami za sosednje pokrajine, ustvarimo dovolj kakovostno sliko o tedanjih podnebnih razmerah in njihovih družbenih posledicah.

Na osnovi podatkov iz kronologije izrednih vremenskih dogodkov je možno sklepati tudi na obdobja z večjo pogostnostjo posameznih dogodkov. Na Slovenskem so se med leti 1700 in 1720 pogosto vrstile pomladi in poletja $\mathrm{z}$ veliko dežja, sredi stoletja so bila topla poletja, ostre zime so se pojavljale med 1630 in 1650 ter v času Maunderjevega minimuma med 1680 in 1716 . V tem času so se med ostrimi zimami pojavljale tudi zelo mile zime. Skozi celotno 17. st. pa je bilo v topli polovici leta zelo veliko nevihtnih neurij. Kljub temu da sodi 17. st. v čas druge polovice male ledene dobe, je iz virov razvidno, da gre za podnebno in vremensko zelo pestro in spremenljivo obdobje, z veliko koncentracijo izrednih vremenskih dogodkov, ki so pomembno vplivali na življenje tedanjih ljudi in družbene razmere.

\section{Viri in literatura}

Camuffo, D., Enzi, S., 1991. Locust invasions and climatic factors from the Middle Ages to 1800 . Theoretical and applied climatology, 43, str. 43-73.

Čufar, K., De Luis, M., Eckstein, D., Kajfež-Bogataj, L., 2008. Reconstructing dry and wet summers in SE Slovenia from oak tree-ring series. International journal of biometeorology, 52, str. 607-615.

Gams, I., 1998. Vreme, sončno obsevanje in temperature. V: Gams, I., Vrišer, I. (ur.). Geografija Slovenije. Ljubljana, Slovenska matica, str. 91-119.

Glaser, R., 2001. Klimageschichte Mitteleuropas: 1000 Jahre Wetter, Klima, Katastrophen. Primus, Darmstadt, 227 str.

Kovačič, F., 1910. Trg Središče. Krajepis in zgodovina z zemljevidom središke občine, z desetimi slikami v tekstu in 24 tablicami. Maribor, Zgodovinsko društvo za Slovenski Štajer, 445 str. (ponatis 1986, Središče ob Dravi).

Levanič, T., 2005. Kronologija macesna (Larix decidua Mill.) za območje jugovzhodnih Alp. Zbornik gozdarstva in lesarstva, 76, str. 39-70.

Levanič, T., 2006. Vpliv klime na debelinsko rast macesna (Larix decidua Mill.) na zgornji gozdni meji v jugovzhodnih Alpah. Zbornik gozdarstva in lesarstva, 78, str. 29-55. 
Levanič, T., 2007. Odziv macesnov (Larix decidua Mill.) na klimo na zgornji gozdni meji in prognoze razvoja debelinskega prirastka v luči klimatskih sprememb. V: Jurc, M. (ur.). Podnebne spremembe: vpliv na gozd in gozdarstvo. Ljubljana, Biotehniška fakulteta, Oddelek za gozdarstvo in obnovljive gozdne vire, str. 305-315.

Levanič, T., Čufar K., 1998. The chronology of silver fir (Abies alba Mill.) from Pohorje, Slovenia. Zbornik gozdarstva in lesarstva, 55, Ljubljana, str. 135-149.

Levec, S., 2009. Vreme in podnebje na Kranjskem od 14. do 18. stoletja s poudarkom na zapisih v Valvasorjevi Slavi vojvodine Kranjske. Diplomsko delo. Ljubljana. Filozofska fakulteta, Oddelek za geografijo in Oddelek za zgodovino, 87 str.

Novak, Z., 1999. Rečica ob Savinji z zaledjem. Zavod za kulturo v Mozirju, 39 str. (transkripcija in transliteracija dela Baš, F.: O Rečici kot trgu. Časopis za zgodovino in narodopisje, 25 (1940), 68 str.).

Ogrin, D., 1994. Modern age climatic fluctuations in the area of the Gulf of Trieste. Geografski zbornik, 34, str. 5-80.

Ogrin, D., 1995. Podnebje Slovenske Istre. Koper, Zgodovinsko društvo za južno Primorsko (Knjižnica Annales, 11), 381 str.

Ogrin, D., 1996. Podnebni tipi v Sloveniji. Geografski vestnik, 68, str. 39-56.

Ogrin, D., 2002. Dry and wet years in Submediterranean Slovenia from the 14th to the mid-19th century. Acta Universitatis Palackianae Olomucensis. Facultas Rerum Naturalium. Geographica, 37, str. 55-62.

Ogrin, D., 2005. Spreminjanje podnebja v holocenu. Geografski vestnik, 77, 1, str. 57-66.

Ogrin, D., 2007a. Olive growing in Slovenian Istria and climatic limitations to its development. Moravian geographical reports, 15, 3, str. 34-40.

Ogrin, D., 2007b. Severe storms and their effects in sub-Mediterranean Slovenia from the 14th to the mid-19th century. Acta geographica Slovenica, 47, 1, str. 7-24.

Ogrin, D., Plut, D., 2009. Aplikativna fizična geografija Slovenije. Ljubljana, Znanstvena založba Filozofske fakultete, 246 str.

Pfister, C., 1995. Monthly temperature and precipitation in Central Europe from 15251979: quantifying documentary evidence on weather and its effect. V: Bradley, R. S., Jones, P. D. (ur.). Climate since A.D. 1500. New York, Routledge, str. 118-142.

Pučnik, J., 1980. Velika knjiga o vremenu. Ljubljana, Cankarjeva založba, 367 str.

Rupel, M., 1969. Valvasorjevo berilo. Ljubljana, Mladinska knjiga, 603 str.

Shindell, D. T., 2009. Little Ice Age, Maunder minimum. V: Gornitz, V. (ur.). Encyclopedia of paleoclimatology and ancient environments. Dordrecht, Springer, str. 520-522, $550-551$.

Slekovec, M., 1885. Župnija sv. Lovrenca na Dravskem polju. Krajepisno-zgodovinske črtice. Maribor, 135 str.

Šifrer, M., 1963. Nova geomorfološka dognanja na Triglavu. Triglavski ledenik v letih 1954-1962. Geografski zbornik, 8, str. 157-210.

Šipec, S., 1999. Pregled naravnih in drugih nesreč leta 1998. Ujma, 13, str. 30-44.

Šipec, S., 2001a. Naravne in druge nesreče v Sloveniji leta 1999. Ujma, 14-15, str. 26-28.

Šipec, S., 2001b. Naravne in druge nesreče v Sloveniji v letu 2000. Ujma, 14-15, str. 29-31. 
Šorn, J., 1950. Donesek h kmečkim uporom v letih 1705 in 1713. Zgodovinski časopis, 4, 1-4, str. 169-183.

The climate of Europe: past, present, and future. Natural and man-induced climatic changes, a European perspective. 1984. Flohn, H., Fantechi, R. (ur.). Dordrecht, D. Reidel, $355 \mathrm{str}$.

Trontelj, M., 1997. Kronika izrednih vremenskih dogodkov XX. stoletja. Ljubljana, Hidrometeorološki zavod Republike Slovenije, 136 str.

Valenčič, V., 1977. Žitna trgovina na Kranjskem in ljubljanske žitne cene od srede 17. stoletja do prve svetovne vojne. Ljubljana, SAZU, 213 str.

Valvasor, J. W., 1689. Die Ehre dess Hertzogthums Crain. I-XV knjiga. Laybach (Ljubljana), 3532 str.

Valvasor, J. V., 1984. Slava vojvodine Kranjske - izbrana poglavja. Ljubljana, Mladinska knjiga, 339 str.

Valvasor, J. V., 2009-2012. Čast in slava vojvodine Kranjske. Ljubljana, Zavod Dežela Kranjska, knjige 1-4, 3552 str.

Vilfan, S., 1954. Prispevki k zgodovini mer na Slovenskem s posebnim ozirom na ljubljansko mero (XVI-XIX. stoletje). Zgodovinski časopis, 8, str. 27-86.

Xoplaki, E., Maheras, P., Luterbacher, J., 2001. Variability of climate in meridional Balkans during the periods 1675-1715 and 1780-1830 and its impact on human life. Climatic change, 48, str. 581-615.

Zwitter, Ž., 2010. Vpliv 'male ledene dobe' na agrarno poselitev na ozemlju današnje Slovenije: na primeru izbranih območij v Zgornji Savinjski dolini. Diplomsko delo. Ljubljana, Filozofska fakulteta, Oddelek za geografijo in Oddelek za zgodovino, 207 str.

Zwitter, Ž., 2012. Podnebne spremembe na Slovenskem v zadnjem tisočletju. Geografija v šoli, 21, 1-2, str. 61-71.

\section{PRESENTATION OF WEATHER AND CLIMATE IN VALVASOR'S GLORY OF THE DUTCHY OF CARNIOLA}

\section{Summary}

It is a lucky coincidence that we have two sources from the 17th century, offering a lot of information about the weather and climate of the time on the Slovenian territory: Valvasor's Glory of the Duchy of Carniola and Dolničar's Ljubljana chronicle. Valvasor's descriptions of weather and climate are not based on technical measurements and observations but just on occasional visual observations by the author and his informers. Certain explanations (and descriptions) are inadequate from the viewpoint of contemporary science, therefore, we only took into consideration those which seemed acceptable to us. The two basic sources are also not concordant in relation to all of the events. A certain degree of inaccuracy can be attributed to Valvasor which calls for additional precaution in the use of this source. Even though the two authors were contemporaries, they only rarely described the same events. This makes us to conclude that there were possibly 
more events than just those about which the two chroniclers obtained information from the information sources of the time.

In spite of all deficiencies we believe that - through a synthesis of all data, by elimination of non-professional explanations, comparison with climate reconstructions made by means of other methods and reconstructions for neighbouring countries - we can establish a sufficiently reliable picture about the climate conditions of that time and their social consequences. It is possible to conclude on the basis of chronology of exceptional weather events that there were also periods of greater frequency of individual events. Between the years 1700 and 1720, springs and summers with lot of rain were frequent in the Slovenian lands, while in the middle of the century summers were warm, and winters were harsh between 1630 and 1650 and during the Maunder minimum period (1680-1716). During that time, very mild winters also occurred in between harsh winters. Throughout the 17th century, there were very many severe storms in the warm half of the year. In spite of the fact that the 17th century belongs to the second half of the Little Ice Age, it is evident from the sources that it was a rather varied period as to the climate and weather, with a great concentration of exceptional weather events which had significant impact on the life of the people of the time and their social circumstances.

(Translated by Branka Klemenc) 